Vol. 1, No. 1, 2020, pp. 23-27

DOI: https://doi.org/10.2921/07essr48000

Contents lists available at Journal IICET

Education and Social Sciences Review

Journal homepage: https://jurnal.iicet.org/index.php/essr

\title{
The concept of anxiety in practice exam among vocational school students
}

Konsep Kecemasan dalam Menghadapi Ujian Praktik Siswa Ujian Praktik Siswa Sekolah Kejuruan

\author{
Tyesa Sri Handayuni ${ }^{1}$, Ifdil Ifdil ${ }^{2}$ \\ ${ }^{12}$ Universitas Negeri Padang
}

\begin{tabular}{ll} 
Article Info & ABSTRACT \\
\cline { 1 - 2 } $\begin{array}{l}\text { Article history: } \\
\text { Received Dec } 19^{\text {th }}, 2020\end{array}$ & $\begin{array}{l}\text { Each student experiences an educational process so that can become a quality } \\
\text { human being in accordance with the objectives of level education are more } \\
\text { revised Jan } 24^{\text {th }}, 2020\end{array}$ \\
Accepted Feb $29^{\text {th }}, 2020$ & $\begin{array}{l}\text { that ared to carry out work practices in accordance with their majors. Things } \\
\text { of which is feeling anxious. Anxiety can be interpreted as a situation where } \\
\text { someone feels afraid, feels depressed, feels worried about things that will } \\
\text { happen, so that can interfere with the learning process. In this article will } \\
\text { explain the concept of anxiety and aspects that affect anxiety that can be } \\
\text { Keyword: }\end{array}$ \\
experience by students in general in vocational high schools.
\end{tabular}

Counseling Service

(C) 2019 The Authors. Published by IICET.

This is an open access article under the CC BY-NC-SA license

(https://creativecommons.org/licenses/by-nc-sa/4.0

\section{Corresponding Author: \\ Tyesa Sri Handayuni, \\ Universitas Negeri Padang \\ Email: tyesasri@gmail.com}

\section{Pendahuluan}

Masa remaja merupakan masa transisi atau perubahan seorang anak-anak menuju orang dewasa dan juga salah satu periode perkembangan pada manusia (Melka, Ahmad, Firman, \& Yarmis, 2019). Secara umum masa remaja terbagi ke dalam dua bagian yaitu remaja awal dan remaja akhir. Pada masa ini seseorang memiliki tugas perkembangan yang harus dilalui dengan baik. Salah satu tugas perkembangan yang harus dilalui remaja sebagai seorang siswa yaitu berkaitan dengan sekolah dan pendidikan tingkat tinggi, yang mampu menggunakan dan mengembangkan keterampilan intelektual dan konsep dalam pembelajaran serta lingkungannya. Remaja yang berusia sekitar 16-21 tahun berada pada tingkat satuan pendidikan Sekolah Lanjut Tingkat Atas (SLTA) baik itu Sekolah Menengah Atas (SMA), Sekolah Menengah Kejuruan (SMK), maupun Madrasah Aliyah (MA). Sejalan dengan hal itu, Peraturan Menteri Pendidikan dan Kebudayaan Republik Indonesia Nomor (17) Tahun (2017) tentang Penerimaan Peserta Didik Baru pada Taman Kanakkanak, Sekolah Dasar, Sekolah Menengah Pertama, sekolah Menengah Atas, Sekolah Menengah Kejuruan, atau Bentuk Lain yang Sederajat menetapkan salah satu persyaratan calon peserta didik baru kelas 10 (sepuluh) SMA, SMK, atau bentuk lain yang sederajat ialah berusia paling tinggi 21 tahun.

Sekolah Menengah Kejuruan (SMK) adalah lembaga pendidikan formal, yang menghasilkan lulusan yang memiliki kompetensi untuk melaksanakan pekerjaan tertentu, serta dapat mengembangkan dirinya secara baik dan profesional, serta mampu beradaptasi pada lingkungan kerja (Etiafani, 2015; Setiawati, 2015). Kompetensi adalah pengetahuan, keterampilan, nilai-nilai dasar, tindakan cerdas, penuh tanggung jawab yang dimiliki oleh seseorang sebagai syarat untuk dianggap mampu dalam melaksanakan tugas-tugas di bidang 
pekerjaan tertentu (Purnomo \& Munadi, 2005). Beberapa kriteria yang menjadi standar dalam penilaian ujian praktik kejuruan yang merujuk pada kompetensi yang di harapkan, yaitu meliputi aspek persiapan kerja, proses (sistematika dan cara kerja), hasil kerja, sikap kerja dan waktu. Dimana siswa dituntut dapat menghasilkan produk sesuai dengan perencanaan dengan waktu kerja (Adiranti, Wardaya, \& Purnawan, 2016).

Kurangnya sarana dan prasarana dalam melakukan praktik membuat siswa memikirkan waktu yang ditetapkan untuk melaksanakan ujian praktik dengan produk yang akan dihasilkan sesuai dengan perencanaan(Adiranti, Wardaya, \& Purnawan, 2016; Susanto, 2016). Siswa yang sedang melaksanakan proses pendidikan tidak jarang mengalami kecemasan. Terlalu cemas ketika akan melakukan praktik kejuruan dan cemas ketika menjelang ujian justru akan mengganggu kejernihan pikiran, keinginan untuk belajar, daya ingat untuk belajar efektif, dan ketangguhan diri (Sari, Mudjiran, \& Alizamar, 2017).

\section{Kecemasan (Anxiety)}

Kecemasan adalah suatu keadaan emosional yang mempunyai ciri-ciri perasaan tegang, tidak nyaman, dan tidak menyenangkan terhadap sesuatu yang buruk akan terjadi (Marjan, Sano, \& Ifdil, 2018). kecemasan juga dapat diartikan sebagai keadaan mental yang tidak menyenangkan yang ditandai oleh kekhawatiran ketidakenakkan dan prarasa yang tidak baik yang tidak bisa terhindarkan (Yanti, Erlamsyah, Zikra, \& Ardi, 2013). Kecemasan merupakan hal yang normal dan menjadi bermanfaat apabila dapat mendorong individu, seperti siswa untuk belajar menjelang ujian (Sari et al., 2017).

Kecemasan adalah hasil dari proses psikologi dan proses fisiologis dalam tubuh manusia, yang menunjukkan reaksi terhadap bahaya yang memperingatkan orang secara naluri/dari dalam, bahwa ada bahaya dan orang yang bersangkutan kemungkinan kehilangan kendali dalam situasi tersebut (Ramaiah, 2003). (Hawari, 2001) mengemukakan kecemasan (ansietas/anxiety) adalah gangguan alam perasaan (affective) yang ditandai dengan perasaan ketakutan atau kekhawatiran, yang mendalam dan berkelanjutan, tidak mengalami gangguan dalam menilai realitas, serta perilaku dapat terganggu tetapi masih dalam batasan yang normal.

Selain itu Freud (dalam Safaria \& Saputra, 2009) menyatakan bahwa kecemasan merupakan reaksi terhadap ancaman dari rasa sakit, maupun dunia luar yang tidak siap ditanggulangi, dan berfungsi untuk memperingatkan individu akan adanya bahaya. Respon perilaku yang khawatir tentang kemungkinan gagal dalam ujian, mengalami kecemasan pada level yang berbeda, dari yang tak terlihat hingga rasa takut berlebihan yang bisa melumpuhkan (Misdeni, Syahniar, \& Marjohan, 2019).

Berdasarkan pendapat para ahli dapat disimpulkan kecemasan adalah suatu kondisi kejiwaan dimana individu tersebut merasa takut, merasa tertekan, mudah tersinggung, sulit berkonsentrasi terhadap hal-hal yang dikerjakan dan hal-hal yang terjadi.

\section{Ciri-ciri Kecemasan}

Menurut (Annisa \& Ifdil, 2016) ciri-ciri individu yang mengalami kecemasan sebagai berikut (1) Gugup, anggota tubuh berkeringat, gelisah, gemetar atau bergetar, mulut atau kerongkongan terasa kering, sulit bernafas, sulit berbicara, jantung berdebar-debar, merasa lemas, pusing, mati rasa, perasaan sensitif dan selalu buang air kecil (kecemasan secara fisik), (2) Ketergantungan dengan orang lain, perasaan terguncang, dan menghindar (secara perilaku), (3) Yakin bahwa sesuatu hal yang mengerikan akan terjadi, takut akan terjadi sesuatu di masa depan, merasa takut akan hilangnya kontrol diri, takut tidak mampu mengatasi masalah, sulit untuk memfokuskan pikiran atau konsentrasi, khawatir akan sesuatu (secara kognitif).

\section{Faktor-faktor Kecemasan}

Faktor-faktor yang mempengaruhi kecemasan adalah pemecahan masalah yang rumit, kurangnya kemampuan yang dimiliki, pengharapan dari orang sekitar terhadap dirinya, kondisi kelas yang kurang kondusif, adanya pengalaman buruk di masa lalu, rendahnya kesiapan dalam belajar, motivasi belajar yang kurang (Aswida, Marjohan, \& Syukur, 2012). Sejalan dengan hal sebelumnya (Amir, 2017) menjelaskan kecemasan dan masalah yang ada pada remaja bisa saja berasal dari hubungan dengan teman dan keluarga, tekanan dan harapan dari diri sendiri maupun orang lain, tekanan dari sekolah oleh guru dan pekerjaan rumah ataupun tugas-tugas, tekanan ekonomi dan kejadian yang ada dalam kehidupan keluarga mereka misalnya kematian, perceraian dan sakit yang di derita oleh anggota keluarganya. 
Sundari (Misdeni et al., 2019) mengemukakan faktor-faktor yang mempengaruhi kecemasan seseorang tidak dapat melakukan penyesuaian pada diri mereka sendiri di lingkungannya, konflik berlebihan dengan perasaan bersalah, dan kesadaran yang tidak jelas, seperti rasa takut yang berlebihan tanpa penyebab yang diketahui.

\section{Bentuk-bentuk Kecemasan}

Menurut Freud (dalam Feist \& Feist, 2010) kecemasan ada tiga jenis atau tiga bentuk, yaitu (1) Kecemasan Neurosis adalah perasaan cemas yang tidak diketahui akibat bahayanya. Perasaan tersebut berada pada ego, tetapi muncul dorongan dari id, (2) Kecemasan moral merupakan rasa takut akan suara hati sendiri, (3) Kecemasan realistik merupakan perasaan yang tidak menyenangkan dan tidak pasti akan kemungkinan bahaya itu sendiri.

\section{Reaksi-reaksi Kecemasan}

Blackburn dan Davidson (dalam Safaria \& Saputra, 2009) berpendapat reaksi kecemasan dapat mempengaruhi suasana hati, pikiran, perilaku motivasi dan gerakan biologis. Kemudian Ramaiah (2003: 9) akibat atau reaksi yang dirasakan ketika seseorang cemas (1) Kepanikan yang amat sangat, karena itu gagal dalam menyesuaikan diri pada situasi (kecemasan traumatik), (2) Gagal mengetahui terlebih dahulu bahayanya dan mengambil tindakan pencegahan yang mencukupi (kecemasan tanda).

\section{Aspek-aspek Kecemasan}

Kecemasan dapat dipengaruhi oleh beberapa aspek yaitu dari suasana hati yang takut terhadap sesuatu yang dianggap mengancam, aspek kognitif yang dipengaruhi oleh pemikiran dan rencana untuk menghindari sesuatu yang mengancam, aspek somatik dan motorik (Stevani, Mudjiran, \& Iswari, 2016). Kemudian Semiun (Misdeni et al., 2019) mengemukakan kecemasan dapat dipengaruhi oleh beberapa aspek, termasuk aspek mood dan kognisi.

Menurut (Zeidner, 1998) ada tiga aspek dalam kecemasan yaitu:

1. Aspek kognitif merupakan aspek yang dianggap sebagai reaksi kognitif yang negatif dari seseorang ketika dihadapkan pada situasi tes. Aspek kognitif terdiri dari kemampuan pemecahan masalah, motivasi dalam mengikuti ujian, serta mengontrol diri ketika akan ujian dan saat ujian

2. Aspek afektif terdiri dari reaksi-reaksi fisiologis dan emosi. Reaksi fisiologis dalam kecemasan seperti gangguan pada lambung, berkeringat, tangan dingin, buang air kecil, mulut kering, tangan atau tubuh gemetar. Sedangkan reaksi emotionality akan sulit memusatkan perhatian pada tugas yang dihadapinya, seperti adanya rasa cemas, khawatir, takut dan tegang.

3. Aspek perilaku merupakan perilaku yang timbul ketika siswa dihadapkan pada situasi saat tes/ujian. Gejala dari perilaku seperti menunda, menghindar dan melarikan diri.

\section{Impilkasi Layanan Bimbingan dan Konseling}

Bimbingan dan konseling adalah salah satu bantuan yang diberikan oleh Guru BK/ Konselor kepada seseorang atau kelompok (klien), guna membantu klien dalam mengatasi permasalahan yang dihadapinya. Bimbingan dan konseling merupakan salah satu komponen yang penting dalam pendidikan di sekolah. Menurut (Prayitno \& Amti, 2004) komponen ini memungkinkan peserta didik untuk mengenal dan menerima lingkungannya secara positif dan dinamis, serta mampu mengambil keputusan, mengarahkan dan mewujudkan diri sendiri secara efektif dan produktif sesuai dengan peranan yang diinginkan di masa depan.

Rasa cemas pada individu salah satunya dapat diatasi dengan kegiatan bimbingan dan konseling. Dengan menggunakan berbagai layanan bimbingan dan konseling, individu akan terbantu untuk mereduksi kecemasan yang ada pada dirinya. Dalam hal ini layanan bimbingan dan konseling yang dapat diberikan oleh Guru BK/ Konselor di sekolah kepada siswa yang mengalami kecemasan yaitu:

1. Layanan informasi merupakan salah satu layanan dalam bimbingan dan konseling yang berupaya memenuhi kekurangan individu akan informasi yang mereka perlukan. Informasi itu kemudian diolah dan digunakan oleh individu untuk kepentingan hidup dan perkembangannya (Prayitno \& Amti, 2004).

2. Layanan penguasan konten merupakan salah satu layanan dalam bimbingan dan konseling yang memungkinkan individu untuk menguasai kemampuan atau kompetensi tertentu yang dipelajari melalui kegiatan belajar (Ahmad, 2013). 
3. Layanan konseling individu merupakan salah satu layanan dalam bimbingan dan konseling yang diselenggarakan oleh seorang konselor/guru BK terhadap seorang klien/siswa dalam rangka pengentasan masalah pribadi klien/siswa (Prayitno \& Amti, 2004).

4. Layanan bimbingan kelompok merupakan salah satu layanan dalam bimbingan dan konseling yang ditujukan kepada sejumlah atau sekelompok orang dengan memanfaatkan dinamika kelompok untuk memperoleh informasi atau pemahaman baru dari topik-topik yang akan dibahas nantinya (Prayitno \& Amti, 2004).

\section{Kesimpulan}

Kecemasan adalah suatu kondisi kejiwaan di mana individu tersebut merasa takut, merasa tertekan, mudah tersinggung, dan sulit berkonsentrasi terhadap hal-hal yang dikerjakan dan hal-hal yang terjadi. ciri-ciri individu yang mengalami kecemasan yaitu gugup, ketergantungan dengan orang lain dan sulit berkonsentrasi. Hal tersebut di pengaruhi oleh pemecahan masalah yang rumit, kurangnya kemampuan yang dimiliki, pengharapan dari konflik yang berlebihan dengan perasaan bersalah, rendahnya kesiapan dalam belajar, serta motivasi belajar yang kurang. Dengan demikian peserta didik terutama siswa SMK perlu dibekali bagaimana konsep kecemasan dalam menghadapi ujian praktik dan hal yang harus dilakukan ketika timbul rasa cemas dengan upaya bantuan dari guru BK, sehingga siswa dapat mereduksi kecemasan yang dirasakannya.

\section{Referensi}

Adiranti, K. K., Wardaya, W., \& Purnawan, P. (2016). Hubungan waktu kerja terhadap hasil kerja pada pelaksanaan uji kompetensi praktik kejuruan bidang pemesinan bubut. Journal of Mechanical Engineering Education, 3(1), 90-98.

Ahmad, R. (2013). Dasar-dasar bimbingan dan konseling. Padang: UNP Press.

Amir, N. (2017). Kecemasan sosial pada remaja yang tinggal di panti asuhan ditinjau dari tipe kepribadian skripsi. Universitas Muhammadiyah Malang.

Annisa, D. F., \& Ifdil, I. (2016). Konsep kecemasan ( anxiety ) pada lanjut usia ( lansia ). Jurnal Konselor, 5(2).

Aswida, W., Marjohan, \& Syukur, Y. (2012). Efektifitas layanan bimbingan kelompok dalam mengurangi kecemasan berkomunikasi pada siswa. Konselor, 1(1), 1-11. https://doi.org/10.24036/0201212697-0-00

Etiafani, A. L. (2015). Self-Regulated Learning Dan Kecemasan Akademik Pada Siswa Smk. Empati, 4(4), $144-149$.

Feist, J., \& Feist, G. J. (2010). Teori Kepribadian, Edisi 7, Terjemahan Handrianto. Jakarta: Salemba Humanika.

Hawari, D. (2001). Manajemen stres, cemas, dan depresi. Jakarta: Balai Penerbit FKUI.

Marjan, F., Sano, A., \& Ifdil, I. (2018). Tingkat kecemasan mahasiswa bimbingan dan konseling dalam menyusun skripsi. JPGI (Jurnal Penelitian Guru Indonesia), $3(2), \quad 84$. https://doi.org/10.29210/02247jpgi0005

Melka, F. D., Ahmad, R., Firman, \& Yarmis, S. (2019). Hubungan kecerdasan emosional dengan penerimaan teman sebaya serta implikasinya dalam Bimbingan dan Konseling. Jurnal Neo Konseling, O(0), 1-7. https://doi.org/10.24036/XXXXXXXXXX-X-XX

Misdeni, M., Syahniar, S., \& Marjohan, M. (2019). The effectiveness of rational emotive behavior therapy approach using a group setting to overcome anxiety of students facing examinations. International Journal of Research in Counseling and Education, 3(2), 82-88. https://doi.org/10.24036/0064za0002

Prayitno, \& Amti, E. (2004). Dasar-dasar bimbingan dan konseling. Jakarta: Rineka Cipta.

Purnomo, E., \& Munadi, S. (2005). Evaluasi hasil belajar dalam implementasi Kurikulum Berbasis Kompetensi di Sekolah Menengah Kejuruan. Cakrawala Pendidikan, 24(2), 259-272.

Ramaiah, S. (2003). Kecemasan (bagaiana mengatasi penyebabnya). Jakarta: Pustaka Populer Obor.

Safaria, T., \& Saputra, N. (2009). Manajemen emosi. Jakarta: Bumi Aksara.

Sari, A. W., Mudjiran, \& Alizamar. (2017). Tingkat kecemasan siswa dalam menghadapi ujian sekolah ditinjau dari jenis kelamin, jurusan dan daerah asal serta implikasi. Jurnal Bikotetik, 1(2), 37-72.

Setiawati, L. (2015). Faktor-faktor yang mempengaruhi prestasi belajar praktik kejuruan siswa SMK program studi keahlian Teknik Komputer Dan Informatika. Jurnal Pendidikan Vokasi, 5(3), 325-339. https://doi.org/http://dx.doi.org/10.1016/S0145-2134\%2802\%2900349-6

Stevani, H., Mudjiran, M., \& Iswari, M. (2016). Efektivitas layanan bimbingan kelompok dengan pendekatan rational emotive behavior therapy untuk mengatasi kecemasan mahasiswa. Konselor, 5(1), 1-9. https://doi.org/10.24036/02016516479-0-00

Susanto, R. (2016). Evaluasi saranan dan prasaranan praktik Teknik Komputer dan Jaringan di SMK Kabupaten Sukoharjo. Jurnal Pendidikan Vokasi, 6(1), 54-65. 
Yanti, S., Erlamsyah, E., Zikra, Z., \& Ardi, Z. (2013). Hubungan antara Kecemasan dalam Belajar dengan Motivasi Belajar Siswa. Konselor, 2(1), 283-288. https://doi.org/10.24036/02013211242-0-00

Zeidner, M. (1998). Anxiety (the state og the art). New York: Kluwer Academic Publisher. 